\title{
Pengendalian status gizi, kadar glukosa darah, dan tekanan darah melalui terapi gizi medis pada pasien diabetes mellitus (DM) tipe 2 rawat jalan di RSU Mataram NTB ${ }^{1}$
}

\author{
Suhaema², Ahmad Husain Asdie ${ }^{3}$, Retno Pangastuti ${ }^{4}$
}

\begin{abstract}
Background: The prevalence of diabetes mellitus (DM) is increasing globally, including in Indonesia. Studies by Diabetes Control and Complication Trial (DCCT) and U.K. Prospective Diabetes Study Group (UKPDS) prove the benefit of medical nutrition therapy (MNT) to glycemic control. Similar studies have not been done much in Indonesia.

Objective: To identify the effects of MNT to nutrient intake, control of nutrition status, blood glucose and blood pressure of type 2 DM outpatients.

Method: This was a randomized controlled trial. Subject of the study consisted of 60 people. The experiment group got MNT; whereas the control group got conventional nutrition counseling. Data were processed using computer, nutrients were analyzed using nutrisurvey. Statistical t-test was done to identify the effect of intervention.

Result: Intake of energy, fat and carbohydrate of the experiment group decreased significantly close to the necessity at subsequent decrease as much as -14.05 ( $p=0.009),-35.64(p=0.019)$ and $-19.14(p=0.035)$. Body mass index In the experiment group decreased $-0.41 \mathrm{~kg} / \mathrm{m}^{2}$ and waist circumference $-0.24 \mathrm{~cm}$, where as the control group $-0.23 \mathrm{~kg} / \mathrm{m}^{2}$ and $-014 \mathrm{~cm}$. Blood glucose level during fasting decreased $-23.6 \mathrm{mg} / \mathrm{dl}$ in the experiment group and $-14.03 \mathrm{mg} / \mathrm{dl}$ in the control group ( $p=0.036$ ). Systolic and dyastolic blood pressure of the experiment group decreased $-3.33 \mathrm{mmHg}(p=0.035)$ and $-1.67 \mathrm{mmgHg}(p=0.895)$, whereas the control group $+0.5 \mathrm{mmHg}$ and $-1.33 \mathrm{mmHg}$; the change was insignificant. Conclusion: Intake of nutrient, nutrition status, blood glucose level and blood pressure of type 2 DM patients that got MNT was more controllable than of those that got conventional nutrition counseling.
\end{abstract}

KEY WORDS MNT, conventional nutrition counseling, type 2 DM, nutrient intake, nutrition status, blood glucose, blood pressure

\section{PENDAHULUAN}

Seiring dengan kemajuan di berbagai bidang dan peningkatan kemakmuran masyarakat, secara global terjadi transisi epidemiologis di mana penyakit degeneratif telah menggeser posisi penyakit infeksi dan kelaparan yang pernah mendominasi dalam beberapa dekade. Salah satu penyakit degeneratif yang prevalensinya terus meningkat adalah diabetes mellitus (DM), terutama DM tipe 2. Peningkatan ini sejalan dengan kecenderungan masyarakat mengkonsumsi makanan fast food yang umumnya mengandung tinggi lemak dan protein, tetapi rendah karbohidrat kompleks khususnya serat $(1,2)$. Hasil penelitian di RSU Sanglah Denpasar menunjukkan bahwa orang yang mempunyai kebiasaan konsumsi serat rendah dengan status gizi obesitas berisiko mengidap DM tipe 2 sebanyak 10,7 kali dan 4,9 kali pada orang yang memiliki kebiasaan mengonsumsi sumber protein hewani berlemak tinggi (3).

Umumnya DM tipe 2 dilatarbelakangi adanya gangguan sekresi dan resistensi insulin, yang berkaitan dengan kondisi komorbid seperti hipertensi, dislipidemia dan obesitas (4). Populasi dengan Indeks Massa Tubuh (IMT) lebih atau sama dengan $25 \mathrm{~kg} / \mathrm{m}^{2}$ memiliki risiko hipertensi lebih tinggi (5). Penelitian di RSU Sanglah Denpasar membuktikan bahwa orang yang hipertensi berisiko 3,7 kali lebih besar untuk mengidap DM tipe 2 (3). Penelitian lain membuktikan keterkaitan antara obesitas dengan sindroma metabolik. Risiko untuk mengalami komorbid berat dijumpai pada orang laki-laki obes yang memiliki Lingkar Pinggang (LP) lebih atau sama dengan $90 \mathrm{~cm}$ dan perempuan lebih atau sama dengan $80 \mathrm{~cm}(6,7,8)$. Buruknya pengendalian kadar glukosa darah, tekanan darah dan kolesterol pengidap DM berkaitan dengan kelebihan berat badan (9). Adapun hasil penelitian di RSU Gunung Jati Cirebon menunjukkan bahwa pengendalian kadar glukosa darah pengidap DM tipe 2 berkaitan dengan pola makan, yaitu asupan karbohidrat (OR: 12,7$)$, lemak (OR: 5,2 ) serta gula dan hasil olahannya (OR: 13) (10).

Penelitian Diabetes Control and Complication Trial (DCCT) dan U.K. Prospective Diabetes Study Group (UKPDS) mengungkapkan peranan penting dari pengendalian glikemik dalam menurunkan komplikasi

\footnotetext{
1 Dipresentasikan pada International Dietetic Update pada tanggal 1517 Oktober 2009 di Yogyakarta kerjasama dengan Asosiasi Dietisien Indonesia, Jurnal Gizi Klinik Indonesia, dan Prodi Gizi Kesehatan FKUGM serta didanai oleh Pendidikan Tinggi Kementerian Pendidikan Nasional.

2 Poltekkes Kemenkes Mataram, Jurusan Gizi, e-mail: emma_sbw2@ yahoo.com

${ }^{3}$ Bagian Penyakit Dalam, Fakultas Kedokteran, Universitas Gadjah Mada

${ }^{4}$ Bagian Instalasi Gizi, RSUP Dr. Sardjito, Jl Kesehatan, Yogyakarta, e-mail: retnopangastuti@gmail.com
} 
kronik vaskuler, dengan Medical Nutrition Therapy (terapi gizi medis: TGM) sebagai faktor penting dalam pencapaian sasaran terapi (11). Hasil penelitian di Amerika Serikat membuktikan bahwa intervensi TGM dan Diabetes SelfManagement Education (DSME) dapat meningkatkan pengendalian glikemik pada penyandang DM (12). Hasil meta-analisis memperjelas manfaat TGM dalam pengendalian DM. Kadar glukosa darah penyandang DM yang mendapat TGM pada awal diagnosis ditegakkan diketahui lebih terkendali dibandingkan dengan yang mendapat TGM setelah mengidap DM selama 4 tahun atau lebih (13).

Penggunaan TGM di Indonesiatelah direkomendasikan sejak tahun 2003 (14). Namun sampai saat ini belum semua rumah sakit melaksanakan TGM sepenuhnya, termasuk rumah sakit umum (RSU) Mataram NTB, sehingga manfaatnya yang besar tidak selalu tampak, bahkan tidak disadari adanya (15). Penelitian di RSUD Kota Bekasi membuktikan bahwa dengan penerapan TGM dalam asuhan gizi pasien rawat inap, rerata asupan energi dan protein pasien mencapai lebih dari $90 \%$, berbeda dengan asuhan gizi konvensional yang asupan pasien masih kurang dari $90 \%$ (16).

Di RSU Mataram, penyakit DM menempati urutan kedua terbanyak setelah hipertensi untuk pasien rawat jalan, yaitu 2.510 orang (16,2\%). Tingginya jumlah ini tidak diikuti dengan kunjungan pasien ke poli gizi, cakupannya hanya sekitar $10 \%$ dari keseluruhan pasien DM rawat jalan (17). Pengamatan terhadap 9 pasien DM tipe 2 dengan obesitas yang mendapat konseling gizi, setelah 2 minggu dijumpai seluruh pasien tidak patuh menjalankan diet serta kadar glukosa darah dan berat badan belum menunjukkan penurunan yang berarti.

Penelitian di RSU Gunung Jati Cirebon menunjukkan bahwa asupan energi, karbohidrat, dan lemak berhubungan dengan pengendalian kadar glukosa darah pada pengidap DM tipe 2 sedangkan asupan protein tidak berhubungan dengan pengendalian kadar glukosa darah (10).

Sedangkan penelitian di RSUD Noongan Sulawesi Utara menunjukkan bahwa konseling gizi dengan buku saku diet dapat mengendalikan kadar asam urat darah pasien hiperusemia. Pengendalian kadar asam urat darah pasien yang diberi konseling gizi dengan buku saku diet terbukti lebih baik dibanding kadar asam urat darah pasien yang diberi konseling gizi tanpa buku saku diet (18).

Penelitian ini bertujuan untuk mengetahui pengaruh TGM terhadap asupan zat gizi, pengendalian status gizi, kadar glukosa darah, dan tekanan darah pasien DM tipe 2 rawat jalan di RSU Mataram NTB.

\section{BAHAN DAN METODE}

Penelitian ini merupakan penelitian eksperimental terkendali acak Randomized Controlled Trial (RCT), dengan rancangan Pretest-Posttest with Control Group. Penelitian dilakukan pada bulan Januari - Juni 2008, dengan populasi penelitian adalah pasien DM tipe 2 rawat jalan di RSU Mataram. Pemilihan subjek berdasarkan kriteria inklusi yaitu menyandang DM kurang dari 2 tahun, belum pernah mendapat konseling gizi, berdomisili di Kota Mataram, dan tidak mengalami komplikasi penyakit jantung, ginjal dan hati. Kriteria eksklusi meliputi: hamil, mengalami gangren, stres berat (menjalani operasi besar dan terjadi serangan jantung.

Subjek penelitian berjumlah 60 orang (kelompok perlakuan dan kontrol). Jumlah tersebut diperoleh dari perhitungan jumlah sampel minimal menggunakan rumus pengujian hipotesis untuk dua rata-rata populasi, yaitu hasil pengalian dari nilai standar deviasi kuadrat dikali $2\left(2 \delta^{2}\right)$ dikali dengan hasil penjumlahan kuadrat dari nilai $z$ pada tingkat kepercayaan 95\% $(z 1-\alpha / 2=1,96)$ dan nilai kekuatan tes $90 \%(z 1-\beta=1,28)$, kemudian hasil pengalian tersebut dibagi dengan nilai rerata perbedaan yang diharapkan dari masingmasing variabel yang dikuadratkan $(\mu 1-\mu 2)^{2}(19)$. Adapun nilai standar deviasi $(\delta)$ yang digunakan untuk masing-masing variabel dalam penelitian ini (kadar glukosa darah puasa, berat badan [BB], IMT, dan tekanan darah sistolik) adalah berdasarkan hasil penelitian di Klinik Universitas Yonsei, Diabetes Center, Severance Hospital di Seoul, Korea Selatan (20). Hasil perhitungan tercantum pada Tabel 1.

Tabel 1. Jumlah sampel minimal berdasarkan kadar glukosa darah puasa, berat badan, IMT, dan tekanan darah sistolik

\begin{tabular}{lccc}
\hline \multicolumn{1}{c}{ Variabel } & $\delta$ & $\mu \mathbf{1}-\mu \mathbf{2}$ & $\mathbf{n}$ \\
\hline Kadar glukosa darah puasa $(\mathrm{mmol})$ & 1,5 & 1,6 & 19 \\
Berat badan $(\mathrm{kg})$ & 2,6 & 2,5 & 23 \\
IMT $\left(\mathrm{kg} / \mathrm{m}^{2}\right)$ & 1,0 & 0,8 & 27 \\
Tekanan darah sistolik $(\mathrm{mmHg})$ & 15,9 & 16,5 & 21 \\
\hline
\end{tabular}

Keterangan: $n=$ jumlah sampel minimal untuk masing-masing kelompok

n : jumlah sampel minimal untuk masing-masing kelompok

z1- $\beta$ : kekuatan (power) test, dalam penelitian ini menggunakan $90 \%(1,28)$

$\mu 1-\mu 2 \quad$ : perbedaan yang diharapkan untuk masing-masing variabel

$z 1-\alpha / 2$ : tingkat kepercayaan, menggunakan 95\% (z1- $\alpha / 2$ $=1,96)$

Jumlah sampel minimal yang digunakan dalam penelitian ini ditetapkan berdasarkan variabel IMT yaitu sebanyak 27 orang. Dengan asumsi 10\% akan lepas dari pengamatan, maka sampel yang dibutuhkan untuk masing-masing kelompok perlakuan dan kelompok kontrol sejumlah 30 orang.

Penempatan subjek dilakukan secara randomisasi sederhana dengan melihat waktu kunjungannya. Subjek yang berkunjung pada minggu ganjil ditempatkan sebagai kelompok perlakuan yang mendapat intervensi TGM, 
sedangkan yang berkunjung pada minggu genap sebagai kontrol yang mendapat konseling gizi konvensional. Intervensi TGM menggunakan panduan modifikasi pedoman TGM dari American Dietetic Association (ADA), 1995 (21). Intervensi TGM dilakukan oleh seorang Ahli gizi dengan pendidikan D-IV gizi klinik (Nutritionis Ahli). Masing-masing subjek mendapat TGM selama 3 kali waktu kunjungan (tahapan sesuai pedoman dengan waktu kunjungan sesuai dengan jadwal yang disepakati). Adapun konseling gizi konvensional dilakukan oleh seorang ahli gizi dengan pendidikan D-IV gizi klinik (Nutritionis Ahli), tanpa pedoman konseling, dilakukan seperti pola atau cara yang selama ini biasa dilakukan sehari-hari di RSU Mataram.

Variabel prediktor dalam penelitian ini adalah dilakukan atau tidaknya TGM. Variabel terikat meliputi asupan zat gizi (energi, protein, lemak dan karbohidrat), status gizi (berdasarkan IMT dan LP), kadar glukosa darah dan tekanan darah. Variabel bebas lain adalah jenis kelamin, umur, onset DM, latihan jasmani, pendidikan dan pengetahuan gizi. Pengumpulan data asupan zat gizi melalui metode food recall $3 \times 24$ jam (sebelum dan setelah penelitian) dan status gizi berdasarkan IMT dan ukuran LP, dilakukan oleh 4 orang enumerator dengan latar belakang pendidikan D-III Gizi. Klasifikasi status gizi berdasarkan IMT menggunakan batasan untuk orang Asia Pasific (WHO/IOTF, 2000). Status gizi berdasarkan LP diklasifikasikan menjadi obes sentral (untuk laki-laki bila $L P \geq 90 \mathrm{~cm}$ dan perempuan bila $L P \geq 80 \mathrm{~cm}$ ) dan tidak obes sentral (untuk laki-laki bila LP $<90 \mathrm{~cm}$ dan perempuan bila LP $<80 \mathrm{~cm}$ ). Pengumpulan data kadar glukosa darah puasa (GDP) ditentukan melalui pemeriksaan GDP dengan metode enzimatik yang dilakukan oleh 1 orang tenaga analis kesehatan, dan tekanan darah diukur menggunakan sphygmomanometer yang dilakukan oleh 1 orang perawat. Pengolahan dan analisis data menggunakan komputer. Asupan zat gizi diolah menggunakan program nutrisurvey. Pengaruh intervensi diukur dengan menggunakan uji statistik independent sample t test.

\section{HASIL DAN BAHASAN}

Karakteristik subjek penelitian disajikan pada Tabel 2. Hasil uji statistik menunjukkan bahwa hampir semua karakteristik subjek pada awal penelitian tidak dijumpai adanya perbedaan bermakna antara kelompok perlakuan dan kontrol, kecuali pada variabel tingkat pengetahuan gizi. Tampak bahwa kelompok perlakuan memiliki rerata tingkat pengetahuan lebih tinggi 4 poin dibandingkan dengan kelompok kontrol.

\section{Pengaruh TGM terhadap asupan zat gizi}

Rerata asupan energi, lemak, dan karbohidrat kelompok perlakuan lebih tinggi dibandingkan dengan kelompok kontrol pada awal penelitian, sebaliknya rerata asupan protein dan natrium lebih tinggi pada kelompok kontrol. Hasil uji statistik menunjukkan bahwa tidak terdapat perbedaan rata-rata asupan energi, lemak, karbohidrat, serat dan natrium antara kelompok perlakuan dan kelompok kontrol ( $p>0,05)$ (Tabel 3).

Tingginya asupan energi dan lemak yang dijumpai pada pasien DM tipe 2 dalam penelitian ini sejalan dengan penelitian sebelumnya yang dilakukan di RSU Sanglah Denpasar (3) dan di RSU Gunung Jati Cirebon (10).

Tabel 2. Distribusi subjek penelitian berdasarkan karakteristik

\begin{tabular}{|c|c|c|c|c|}
\hline \multirow{3}{*}{ Karakteristik } & \multirow{3}{*}{$\mathbf{F} / \chi^{2}$} & Perlakuan & Kontrol & \multirow{3}{*}{$\mathbf{p}$} \\
\hline & & Mean (SD) & Mean (SD) & \\
\hline & & n (\%) & n (\%) & \\
\hline Umur & $F=0,007$ & $54,27( \pm 9,28)$ & $55,63( \pm 9,22)$ & 0,569 \\
\hline Jenis kelamin & $\chi^{2}=0,269$ & & & 0,604 \\
\hline Laki-laki & & $18(60 \%)$ & $15(50 \%)$ & \\
\hline Perempuan & & $12(40 \%)$ & $15(50 \%)$ & \\
\hline Pendidikan & $x^{2}=8,236$ & & & 0,083 \\
\hline PT & & $8(26,7 \%)$ & $14(46,7 \%)$ & \\
\hline SMA & & $10(33,3 \%)$ & $6(20,0 \%)$ & \\
\hline SMP & & $6(20,0 \%)$ & $3(10,0 \%)$ & \\
\hline $\mathrm{SD} /$ & & $6(20,0 \%)$ & $7(23,3 \%)$ & \\
\hline Tidak sekolah & & & & \\
\hline Pengetahuan gizi & $F=0,01$ & Mean (SD) & Mean (SD) & 0,038 \\
\hline Onset DM & $\chi^{2}=3,326$ & $86,20( \pm 6,23)$ & $82, / /( \pm 6,29)$ & 0,068 \\
\hline$<1$ th (th.2008) & & $13(43,3 \%)$ & $21(70 \%)$ & \\
\hline $1-2$ th (th.2007) & & $17(56,7 \%)$ & $9(30 \%)$ & \\
\hline Hipertensi & $\chi^{2}=1,697$ & & & 0,193 \\
\hline Ya & & $14(46,7 \%)$ & $20(66,7 \%)$ & \\
\hline Tidak & & $16(53,3 \%)$ & $10(33,3 \%)$ & \\
\hline Latihan jasmani & $\chi^{2}=0,274$ & & & 0,600 \\
\hline Ya & & $19(63,3 \%)$ & $16(53,3 \%)$ & \\
\hline Tidak & & $11(36,7 \%)$ & $14(46,7 \%)$ & \\
\hline
\end{tabular}


Tabel 3. Rerata asupan zat gizi kelompok perlakuan dan kontrol pada awal penelitian

\begin{tabular}{|c|c|c|c|c|}
\hline \multirow{2}{*}{ Jenis zat gizi } & Perlakuan & Kontrol & \multirow{2}{*}{$\mathbf{F}$} & \multirow{2}{*}{$\mathbf{P}$} \\
\hline & Mean (SD) & Mean (SD) & & \\
\hline Energi (\%) & $120,96( \pm 17,13)$ & $116,23( \pm 14,93)$ & 1,134 & 0,259 \\
\hline Protein (\%) & $91,975( \pm 25,04)$ & $95,50( \pm 30,08)$ & 1,707 & 0,623 \\
\hline Lemak (\%) & $141,42( \pm 42,96)$ & $120,99( \pm 42,49)$ & 0,180 & 0,069 \\
\hline Karbohidrat (\%) & $106,37( \pm 17,80)$ & $100,31( \pm 16,82)$ & 0,029 & 0,184 \\
\hline Natrium (\%) & $133,49(45,02)$ & $141,36(52,52)$ & 0,308 & 0,539 \\
\hline
\end{tabular}

Tabel 4. Perbedaan asupan zat gizi kelompok perlakuan dan kontrol

\begin{tabular}{|c|c|c|c|c|c|c|}
\hline \multirow{3}{*}{ Jenis zat gizi } & \multicolumn{2}{|c|}{ Perlakuan } & \multirow{3}{*}{$\mathbf{p}$} & \multicolumn{2}{|c|}{ Kontrol } & \multirow{3}{*}{$\mathbf{p}$} \\
\hline & \multicolumn{2}{|c|}{ Mean (SD) } & & \multicolumn{2}{|c|}{ Mean (SD) } & \\
\hline & Awal & Akhir & & Awal & Akhir & \\
\hline Energi $(\%)$ & $\begin{array}{c}120,96 \\
( \pm 17,13)\end{array}$ & $\begin{array}{c}106,93 \\
( \pm 3,55)\end{array}$ & $<0,001$ & $\begin{array}{c}116,23 \\
( \pm 14,93)\end{array}$ & $\begin{array}{c}113,07 \\
( \pm 8,39)\end{array}$ & 0,238 \\
\hline Protein (\%) & $\begin{array}{c}91,98 \\
( \pm 25,04)\end{array}$ & $\begin{array}{c}87,21 \\
( \pm 17,05)\end{array}$ & 0,280 & $\begin{array}{c}95,50 \\
( \pm 30,08)\end{array}$ & $\begin{array}{c}95,44 \\
( \pm 23,52)\end{array}$ & 0,992 \\
\hline Lemak (\%) & $\begin{array}{c}141,42 \\
( \pm 42,97)\end{array}$ & $\begin{array}{c}104,52 \\
( \pm 28,62)\end{array}$ & $<0,001$ & $\begin{array}{c}120,99 \\
( \pm 42,49)\end{array}$ & $\begin{array}{c}111,21 \\
( \pm 31,41)\end{array}$ & 0,224 \\
\hline Karbohidrat (\%) & $\begin{array}{c}106,32 \\
( \pm 18,48)\end{array}$ & $\begin{array}{c}87,43 \\
( \pm 18,48)\end{array}$ & $<0,001$ & $\begin{array}{c}100,31 \\
( \pm 21,16)\end{array}$ & $\begin{array}{c}92,89 \\
( \pm 26,63)\end{array}$ & 0,041 \\
\hline Natrium (\%) & $\begin{array}{c}133,55 \\
( \pm 44,99)\end{array}$ & $\begin{array}{c}122,49 \\
( \pm 30,75)\end{array}$ & 0,010 & $\begin{array}{c}141,36 \\
( \pm 52,52)\end{array}$ & $\begin{array}{c}134,85 \\
( \pm 50,15)\end{array}$ & 0,023 \\
\hline
\end{tabular}

Tabel 5. Delta perubahan asupan zat gizi kelompok perlakuan dan kontrol

\begin{tabular}{lcccc}
\hline \multicolumn{1}{c}{ Jenis zat gizi } & Perlakuan & Kontrol & \multirow{2}{*}{ F } & P \\
\cline { 2 - 3 } & Mean (SD) & Mean (SD) & & \\
\hline Energi (\%) & $-14,05( \pm 16,41)$ & $-3,24( \pm 14,43)$ & 1,217 & 0,009 \\
Protein (\%) & $-3,37( \pm 25,63)$ & $-0,07( \pm 34,23)$ & 5,011 & 0,539 \\
Lemak (\%) & $-35,64( \pm 40,41)$ & $-10,46( \pm 46,0)$ & 2,031 & 0,019 \\
Karbohidrat (\%) & $-19,14( \pm 22,97)$ & $-0,07( \pm 25,49)$ & 1,315 & 0,035 \\
Natrium (\%) & $-11,05( \pm 19,93)$ & $-6,51( \pm 14,88)$ & 1,474 & 0,452 \\
\hline
\end{tabular}

Pada Tabel 4 tampak rata-rata asupan zat gizi mengalami penurunan di kedua kelompok. Secara statistik pada kelompok perlakuan ditemukan penurunan bermakna rerata asupan energi, lemak, karbohidrat $(p<0,001)$ dan natrium $(p<0,05)$, sedangkan kelompok kontrol terlihat pada asupan karbohidrat dan natrium $(p<0,05)$.

Namun berdasarkan delta perubahan asupan zat gizi (Tabel 5), perbedaan bermakna secara statistik hanya dijumpai pada asupan energi, lemak dan karbohidrat $(p<0,05)$, sedangkan protein dan natrium tidak berbeda $(p>0,05)$.

Hasil penelitian ini sejalan dengan penelitian pada penduduk perkotaan (Ras African American) yang menyandang DM tipe 2 yang berobat di The Grady Health System Diabetes Clinic Amerika tahun 2003, yang menemukan adanya penurunan bermakna asupan energi dan lemak setelah pasien mendapat TGM. Demikian pula dengan hasil penelitian di Amerika Serikat yang mendapatkan manfaat serupa dari penerapan TGM dan pelatihan pengelolaan diabetes mandiri selama 6 bulan pada 102 pasien DM tipe 1 dan DM tipe 2. Asupan lemak dan gula pasien berhasil diturunkan melalui TGM. Pasien diberi alat bantu berupa gambar piramida makanan atau mendapat perencanaan makan dengan disertai daftar penukar. Berdasarkan penelitian tersebut tampak rata-rata pengetahuan subjek meningkat dari sebelumnya, dan hal tersebut yang mendasari perubahan perilaku makannya, yang terlihat pada penurunan asupan mendekati jumlah yang dianjurkan $(12,22,23)$. Penelitian di RSUD Bekasi juga mendapatkan asupan zat gizi pasien rawat inap dengan TGM mempunyai rata-rata mendekati jumlah yang direkomendasikan, dengan rerata mencapai lebih dari $90 \%$. Asupan tersebut lebih tinggi dari pasien yang mendapat terapi gizi konvensional, dengan rerata asupannya kurang dari $90 \%$ (16).

Demikian pula pada penelitian ini, di awal penelitian diperoleh data bahwa $47 \%$ subjek tidak mengetahui bahwa penyakit DM merupakan penyakit yang akan disandang seumur hidup sehingga memerlukan pengelolaan yang baik. Terdapat $35 \%$ subjek menyatakan bahwa penyandang DM tidak perlu melakukan pengaturan makan apabila telah mendapat terapi obat. Selain itu terdapat $30 \%$ subjek yang menyatakan bahwa penyandang DM hanya diperbolehkan mengonsumsi jenis buah tertentu saja (tidak semua buah boleh dikonsumsi oleh penyandang DM meskipun jumlahnya sudah diperhitungkan). 
Berdasarkan temuan tersebut kemudian dietisien menindaklanjutinya dengan memberikan edukasi secara berkesinambungan mengenai pengelolaan diabetes, disertai dengan pengetahuan dasar lainnya yang harus diketahui oleh penyandang DM termasuk perencanaan makan. Sebagaimana ditegaskan bahwa TGM merupakan suatu proses asuhan gizi yang membantu klien untuk melakukan perubahan gaya hidup dalam rangka pengobatan penyakit (24) maka melalui TGM dietisien dapat menemukan permasalahan klien sekaligus memberikan alternatif solusi terhadap permasalahan yang menghambat perubahan tersebut. Melalui TGM, memungkinkan bagi dietisien untuk melakukan perubahan bermakna bagi penyandang diabetes, karena selain menekankan pentingnya pengaturan makan, TGM juga menekankan pentingnya edukasi mengenai perawatan DM secara mandiri serta motivasi kepada pasien untuk melakukan perubahan gaya hidup $(25,26)$.

Selain itu, mengacu pada tahapan perubahan perilaku Transtheoretical Models, bahwa perubahan kebiasaan makan seseorang terlihat pada tahap action, di mana perubahan perilaku individu akan dilakukan setelah memahami manfaat perubahan yang dilakukan terhadap penyakit yang dialaminya. Namun bagi yang berada pada tahap precontemplation, yaitu individu yang belum tertarik (belum menunjukkan sambutan positif) terhadap terapi yang diberikan, membutuhkan pendekatan yang lebih bersifat individual (27). Hal inilah yang difasilitasi oleh TGM, dengan disusunnya pedoman TGM dalam 3 tahap kunjungan memberi peluang kepada dietisien untuk lebih memahami permasalahan yang dialami pasien terkait terapi diet yang diberikan. Selanjutnya permasalahan yang dihadapi tersebut dapat didiskusikan kembali dan diperbaiki bersama pasien pada kunjungan berikutnya, hingga mencapai tujuan terapi.

\section{Pengaruh TGM terhadap pengendalian status gizi}

Status gizi pada subjek penelitian ditentukan melalui perhitungan IMT dan ukuran lingkar pinggang (LP).
Berdasarkan IMT tampak kelompok perlakuan dalam status gizi overweight (IMT 23-24,9 kg/m²) dengan rerata sebesar $24,98 \mathrm{~kg} / \mathrm{m}^{2}(\mathrm{SD} \pm 3,74)$, sedangkan kelompok kontrol mengalami obesitas (IMT $\geq 25 \mathrm{~kg} / \mathrm{m}^{2}$ ) dengan rerata 26,00 $\mathrm{kg} / \mathrm{m}^{2}(\mathrm{SD} \pm 4,79)$, tetapi perbedaan tersebut tidak bermakna secara statistik $(p>0,05)$. Penelitian di Rumah Sakit Sanglah Denpasar juga mendapatkan kejadian DM tipe 2 dijumpai lebih sering pada pasien dengan obesitas (OR:10,7; 95\% Cl:3,5-33,7) (3).

Setelah dilakukan intervensi tampak adanya penurunan rerata IMT pada kelompok perlakuan dan kelompok kontrol. Kelompok perlakuan mengalami penurunan IMT lebih banyak daripada kelompok kontrol yaitu sebesar $0,41 \mathrm{~kg} /$ $\mathrm{m}^{2}(\mathrm{SD} \pm 0,41)$, sedangkan kelompok kontrol sebesar 0,23 $\mathrm{kg} / \mathrm{m}^{2}(\mathrm{SD} \pm 0,5)$. Berdasarkan analisis statistik diketahui adanya perbedaan bermakna antara IMT awal dengan akhir penelitian pada kelompok perlakuan dan kontrol $(p<0,001)$, namun berdasarkan delta perubahan IMT (Tabel 6) diketahui bahwa IMT antara kelompok perlakuan dan kelompok kontrol tidak berbeda $(p>0,05)$.

Apabila dilihat dari kriteria pengendalian IMT, maka tampak perubahan proporsi pada kedua kelompok, disajikan pada Tabel 7. Penambahan proporsi IMT terkendali baik pada kelompok perlakuan lebih banyak daripada kontrol.

Berdasarkan hasil pengukuran LP, diketahui rata-rata LP kelompok perlakuan lebih rendah dari kelompok kontrol (Gambar 1) yaitu 90,9 cm (SD $\pm 6,39$ ) sedangkan kelompok kontrol sebesar 92,2 cm (SD $\pm 13,85)$. Hasil uji statistik menunjukkan tidak ada perbedaan rerata ukuran LP antara kelompok perlakuan dengan kelompok kontrol $(p>0,05)$.

Ukuran LP bila dikelompokkan ke dalam kategori obes sentral (ukuran LP laki-laki $\geq 90 \mathrm{~cm}$ dan perempuan $\geq 80 \mathrm{~cm}$ ) dan tidak obes sentral (ukuran LP laki-laki $<90$ $\mathrm{cm}$ dan perempuan $<80 \mathrm{~cm}$ ), maka didapatkan sebagian besar subjek penelitian termasuk dalam kategori obes sentral, yaitu berjumlah 43 orang $(71,1 \%)$, masing-masing 21 orang (35\%) pada kelompok perlakuan dan 22 orang $(36,7 \%)$ pada kelompok kontrol.

Tabel 6. Perubahan IMT kelompok perlakuan dan kontrol

\begin{tabular}{lcccc}
\hline \multirow{2}{*}{ IMT } & \multicolumn{2}{c}{ Perlakuan } & \multicolumn{2}{c}{ Kontrol } \\
\cline { 2 - 5 } & Mean (SD) & $\mathbf{p}$ & Mean (SD) & $\mathbf{p}$ \\
\hline IMT awal $\left(\mathrm{kg} / \mathrm{m}^{2}\right)$ & $24,98( \pm 3,74)$ & $<0,001$ & $26,00( \pm 4,79)$ & 0,019 \\
IMT akhir $\left(\mathrm{kg} / \mathrm{m}^{2}\right)$ & $24,57( \pm 3,45)$ & & $25,78( \pm 4,83)$ & $\mathrm{F}=0,558$ \\
Delta IMT $\left(\mathrm{kg} / \mathrm{m}^{2}\right)$ & $-0,41( \pm 0,41)$ & & $-0,23( \pm 0,49)$ & $\mathrm{p}=0,134$ \\
\hline
\end{tabular}

Tabel 7. Perubahan pengendalian IMT kelompok perlakuan dan kontrol

\begin{tabular}{|c|c|c|c|c|}
\hline \multirow[b]{2}{*}{$\begin{array}{c}\text { Kategori } \\
\text { pengendalian IMT }\end{array}$} & \multicolumn{2}{|c|}{ Perlakuan } & \multicolumn{2}{|c|}{ Kontrol } \\
\hline & $\begin{array}{l}\text { Awal } \\
\text { n (\%) } \\
\end{array}$ & $\begin{array}{l}\text { Akhir } \\
\text { n (\%) }\end{array}$ & $\begin{array}{l}\text { Awal } \\
\text { n (\%) } \\
\end{array}$ & $\begin{array}{l}\text { Akhir } \\
\text { n (\%) }\end{array}$ \\
\hline $\begin{array}{l}\text { Baik }(18,5-22,9) \\
\text { Sedang }(23-24,9) \\
\text { Buruk }(\geq 25)\end{array}$ & $\begin{array}{c}10(33,3 \%) \\
5(16,7 \%) \\
15(50 \%)\end{array}$ & $\begin{array}{c}12(40 \%) \\
6(20 \%) \\
12(40 \%)\end{array}$ & $\begin{array}{l}5(16,7 \%) \\
8(26,7 \%) \\
17(56,7 \%)\end{array}$ & $\begin{array}{l}6(20 \%) \\
6(20 \%) \\
18(60 \%)\end{array}$ \\
\hline
\end{tabular}




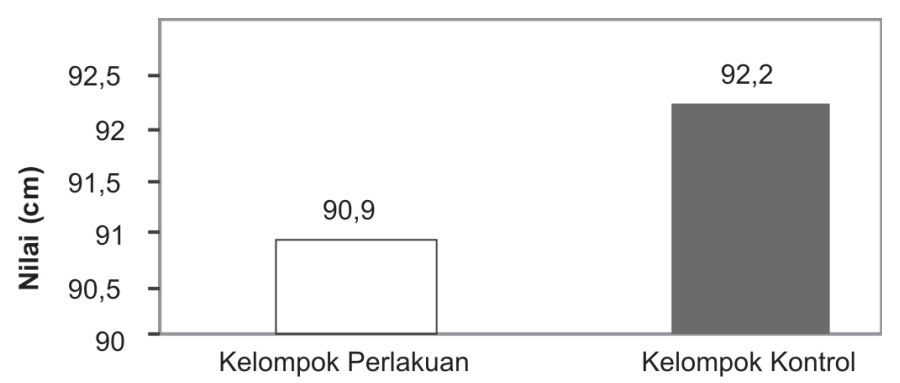

Gambar 1. Rerata ukuran LP awal kelompok perlakuan dan kontrol

Pada akhir penelitian tampak bahwa kedua kelompok mengalami penurunan ukuran LP, masing-masing sebesar $0,25 \mathrm{~cm}(\mathrm{SD} \pm 0,32)$ pada kelompok perlakuan dan 0,14 $\mathrm{cm}(\mathrm{SD} \pm 0,32)$ pada kelompok kontrol. Akan tetapi bila dilihat dari kriteria obes sentral dan tidak obes sentral, maka dijumpai proporsi obes sentral hanya menurun pada kelompok perlakuan (Gambar 2).

Hasil analisis statistik menunjukkan adanya perbedaan bermakna ukuran LP awal dan akhir penelitian pada kelompok perlakuan $(p<0,001)$. Pada kelompok kontrol, perbedaan ukuran LP tidak bermakna secara statistik $(p>0,05)$. Hasil analisis delta perubahan LP (Tabel 8) diketahui tidak ada perbedaan antara kelompok perlakuan dan kelompok kontrol.

Beberapa penelitian sebelumnya melaporkan hal yang sejalan dengan penelitian ini, terutama dengan outcome penurunan BB atau IMT. Penelitian pada pasien DM tipe 2 yang mengalami overweight dan obesitas yang mendapat TGM dan latihan jasmani, setelah 6 bulan dijumpai rerata penurunan BB sebesar 7,8\% (IMT menurun sekitar 3,3 $\pm 4,1$ unit). Hasil meta-analisis mengenai efek konseling perencanaan makan terhadap penurunan BB terbukti rerata IMT menurun 2 unit (6\%) setelah 1 tahun atau rerata menurun 0,1 unit setiap bulan setelah bulan ketiga. Penurunan IMT ini terkait dengan penurunan asupan kalori dan total lemak $(28,29)$.

Pada penelitian ini juga dijumpai adanya penurunan IMT dan penurunan asupan energi, lemak dan karbohidrat
Tabel 8. Perubahan lingkar pinggang kelompok perlakuan dan kontrol

\begin{tabular}{lcccc}
\hline & \multicolumn{2}{c}{ Perlakuan } & \multicolumn{2}{c}{ Kontrol } \\
\cline { 2 - 5 } & Mean (SD) & $\mathbf{p}$ & Mean (SD) & $\mathbf{p}$ \\
\hline $\begin{array}{l}\text { LP awal } \\
(\mathrm{cm})\end{array}$ & $90,98( \pm 6,39)$ & $<0,001$ & $92,19( \pm 13,86)$ & 0,055 \\
$\begin{array}{l}\text { LP akhir } \\
(\mathrm{cm})\end{array}$ & $90,74( \pm 6,28)$ & & $92,05( \pm 13,83)$ & $\mathrm{F}=1,897$ \\
$\begin{array}{l}\text { Delta LP } \\
(\mathrm{cm})\end{array}$ & $-0,24( \pm 0,33)$ & $-0,14( \pm 0,37)$ & $\mathrm{p}=0,276$ \\
\hline
\end{tabular}

pada kedua kelompok. Rerata asupan energi kelompok perlakuan menurun sebesar $14,05 \%$ dari kebutuhan total energi $( \pm 16,41)$ setara dengan pengurangan $240 \mathrm{kkal}$, sedangkan kelompok kontrol hanya menurun 3,24\% $( \pm 14,43)$ yaitu sekitar $65 \mathrm{kkal}$. Pengurangan rata-rata asupan energi sebesar 250-500 kkal dari asupan seharihari mempunyai efek terhadap penurunan BB sekitar 2-4 kg per bulan (30). Pada penelitian ini dijumpai rata-rata penurunan BB kelompok perlakuan sebesar $1,07 \mathrm{~kg}$ atau rata-rata IMT menurun sebesar 0,41 $( \pm 0,41)$.

Mengenai efek TGM terhadap penurunan ukuran LP belum banyak dilaporkan. Dijelaskan oleh para pakar bahwa penurunan BB pada penyandang DM tipe 2 akan diiringi dengan penurunan obesitas abdominal dan rasio lingkar pinggang panggul (31). Setiap lemak dan karbohidrat makanan yang tidak langsung digunakan tubuh akan disimpan di jaringan adiposa di bawah kulit atau di rongga perut dalam bentuk trigliserida. Pengurangan asupan makanan dapat mengakibatkan terjadinya penurunan BB yang disertai dengan penurunan total massa lemak tubuh, termasuk lemak pada jaringan lemak subkutan abdominal (32). Sebaliknya peningkatan konsumsi makanan yang berdensitas energi tinggi berkaitan dengan tingginya nilai IMT dan ukuran LP (33).

Bila dikaitkan dengan sifat dari lemak visceral yang mudah mengalami lipolisis (6), maka pada kondisi adanya pengurangan asupan lemak dan karbohidrat dalam jangka waktu relatif lama, maka dapat terjadi penurunan

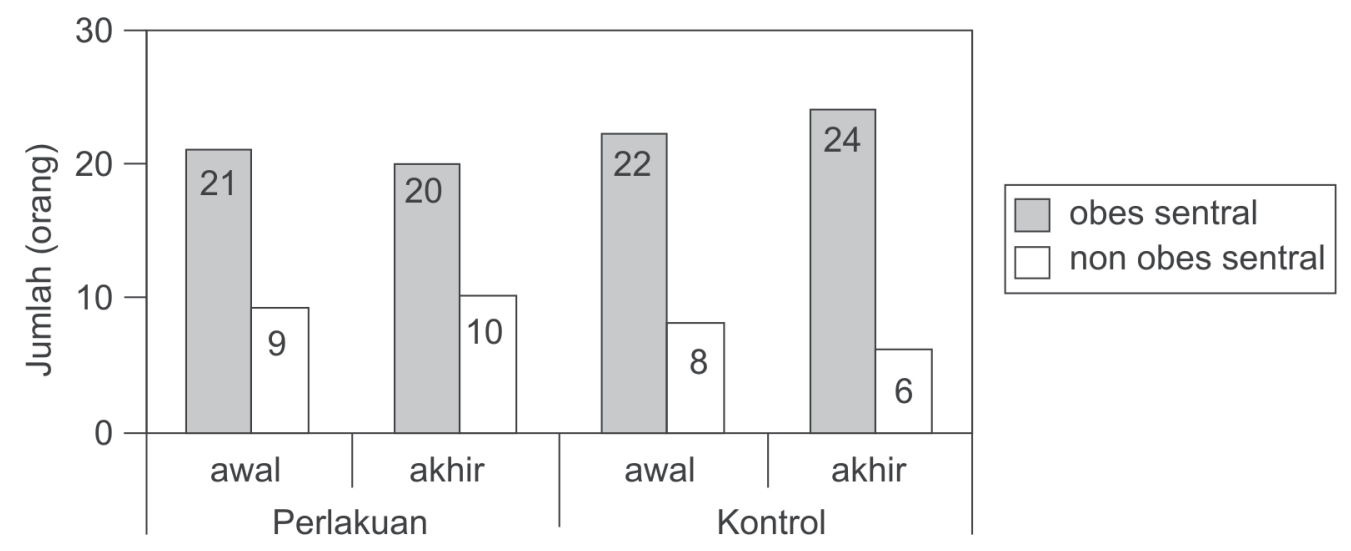

Gambar 2. Perbedaan proporsi obes sentral kelompok perlakuan dan kontrol 
cadangan lemak pada jaringan adiposa karena simpanan tersebut digunakan untuk pemenuhan kebutuhan energi. Sebagaimana dalam penelitian ini dijumpai penurunan rerata asupan lemak dan karbohidrat secara berurutan pada kelompok perlakuan dan kontrol masing-masing asupan lemak sebesar 35,64\% dari total kebutuhan energi dan $10,46 \%$ serta karbohidrat sebesar $19,14 \%$ dan 0,07\%, yang diikuti dengan penurunan ukuran LP sebesar $0,24 \mathrm{~cm}$ pada kelompok perlakuan dan 0,14 cm pada kelompok kontrol.

Tidak adanya perbedaan bermakna IMT dan LP pada kedua kelompok, kemungkinan disebabkan kedua intervensi tersebut sama-sama bertujuan untuk memotivasi pasien agar melakukan perubahan gaya hidup termasuk perbaikan asupan zat gizi dan status gizi penyandang DM tipe 2. Kemungkinan lain juga terkait dengan waktu penelitian yang relatif singkat, sehingga tidak mampu menunjukkan perubahan berarti pada IMT dan LP. Hasil review tentang efektivitas self management training pada DM tipe 2 menyimpulkan bahwa perubahan IMT penyandang DM terlihat nyata pada penelitian dengan intervensi intensif dalam jangka waktu lama (34).

\section{Pengaruh TGM terhadap kadar glukosa darah}

Berdasarkan hasil pengukuran kadar GDP, diperoleh rerata kadar GDP kelompok perlakuan lebih tinggi dari kelompok kontrol, dengan kadar GDP kelompok perlakuan sebesar 191,93 mg/dl (SD $\pm 28,23)$ dan kelompok kontrol $185,97 \mathrm{mg} / \mathrm{dl}(\mathrm{SD} \pm 27,12)$. Namun demikian, perbedaan tersebut secara statistik tidak bermakna $(p>0,05)$.

Hasil penelitian didapatkan penurunan kadar GDP pada kelompok perlakuan dan kontrol, masing-masing sebesar 23,6 mg/dL (SD $\pm 16,67)$ dan 14,03 mg/dL (SD $\pm 17,87)$. Perbedaan perubahan kadar GDP pada kelompok perlakuan dan kontrol disajikan pada Gambar 3.

Hasil uji statistik menunjukkan bahwa pada kelompok perlakuan terdapat perbedaan bermakna antara kadar GDP awal dan akhir penelitian $(p<0,05)$, sedangkan pada kelompok kontrol secara statistik tidak berbeda $(p>0,05)$.

Adapun hasil analisis terhadap delta perubahan kadar glukosa darah ditemukan adanya perbedaan bermakna antara kelompok perlakuan dan kontrol $(p<0,05)$, yang menunjukkan bahwa intervensi TGM berpengaruh terhadap pengendalian kadar GDP pasien DM tipe 2 (Tabel 9).

Hasil penelitian ini didukung dengan hasil penelitian sebelumnya, bahwa penerapan TGM dengan menggunakan

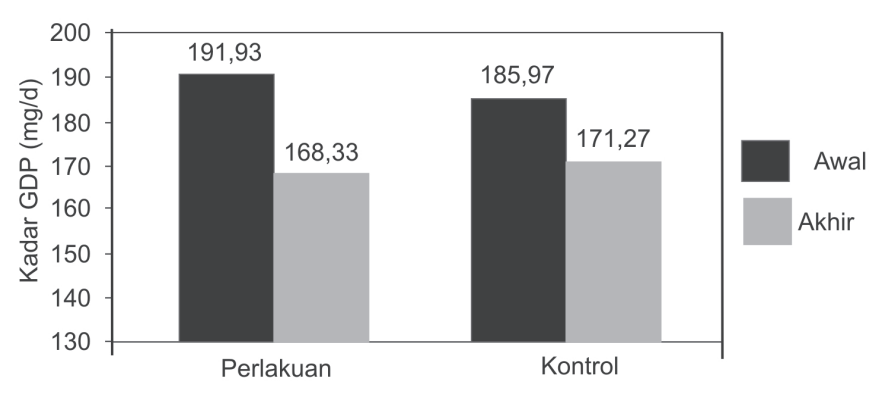

Gambar 3. Perbedaan kadar GDP kelompok perlakuan dan kontrol

pedoman praktik mempunyai efek terhadap penurunan kadar glukosa darah puasa pasien DM tipe 2 sebesar $20 \%$ setelah 6 bulan atau sekitar 4,4-7,8 mmol/dL (35). Penelitian lain di Amerika Serikat melaporkan efek TGM terhadap penurunan kadar GDP yaitu sebesar 30-50 mg/dL (36).

Penurunan kadar glukosa darah puasa berkaitan dengan asupan zat gizi terutama energi, lemak dan karbohidrat serta penurunan IMT dan LP. Penurunan asupan energi moderat sekitar 250-500 kkal setiap hari dari jumlah asupan sehari-hari dapat menurunkan BB sekitar $0,5-1 \mathrm{~kg}$ per minggu (30), dan penurunan $B B$ sekitar 5-10\% dapat memperbaiki pengendalian glukosa darah (2). Penurunan BB dapat diikuti dengan menurunnya kadar GDP (28).

Pada penelitian ini, rerata asupan energi pasien menurun $14,05 \%$ (setara dengan $240 \mathrm{kkal}$ ) dan BB menurun $1,07 \mathrm{~kg}$, disertai pula dengan penurunan kadar GDP, meskipun dengan penurunan yang lebih rendah dari penelitian sebelumnya yaitu sebesar $23,6 \mathrm{mg} / \mathrm{dL}( \pm 16,67)$. Perbedaan ini kemungkinan karena waktu penelitian yang lebih singkat setengah dari penelitian sebelumnya yang memberi efek terhadap penurunan kadar glukosa darah lebih banyak.

Penurunan kadar glukosa darah pada penyandang DM tipe 2, menurut pendapat pakar umumnya terjadi akibat perbaikan resistensi insulin, baik sebagai efek dari penurunan atau perbaikan asupan zat gizi atau efek dari peningkatan pengeluaran energi, yang berdampak terhadap penurunan BB. Penurunan BB ini akan mengakibatkan menurunnya kadar trigliserida darah yang kemudian diikuti dengan penurunan kebutuhan insulin dan sebaliknya sensitivitas insulin akan membaik, sehingga terjadi perbaikan kendali glukosa darah $(2,37)$.

Tabel 9. Analisis statistik terhadap perubahan kadar GDP

\begin{tabular}{lcccc}
\hline & Perlakuan & \multicolumn{2}{c}{ Kontrol } \\
\cline { 2 - 5 } & Mean (SD) & $\mathbf{p}$ & Mean (SD) & $\mathbf{p}$ \\
\hline GDP awal $(\mathrm{mg} / \mathrm{dL})$ & $191,93( \pm 28,23)$ & $<0,001$ & $185,97( \pm 27,12)$ & 0,079 \\
GDP akhir $(\mathrm{mg} / \mathrm{dL})$ & $168,33( \pm 33,28)$ & & $171,27( \pm 25,80)$ & $\mathrm{F}=0,346$ \\
Delta GDP $(\mathrm{mg} / \mathrm{dL})$ & $-23,6( \pm 16,67)$ & & $-14,03( \pm 17,87)$ & $\mathrm{p}=0,036$ \\
\hline
\end{tabular}




\section{Pengaruh TGM terhadap tekanan darah}

Adapun hasil pengukuran tekanan darah, pada awal penelitian diperoleh rerata tekanan darah kelompok perlakuan lebih rendah dibandingkan kelompok kontrol. Kelompok perlakuan memiliki rerata tekanan darah sistolik(TDS)/tekanan darah diastolik (TDD) sebesar $135,33 / 83,67 \mathrm{mmHg}$ (SD $\pm 19,78 / 9,91)$, sedangkan kelompok kontrol sebesar 137,33/84,83 mmHg (SD $\pm 15,74 / 7,82)$. Hasil analisis statistik menunjukkan tidak ada perbedaan rata-rata tekanan darah antara kelompok perlakuan dan kelompok kontrol $(p<0,005)$.

Hasil penelitian menunjukkan bahwa TDS menurun pada kedua kelompok, tetapi TDD hanya menurun pada kelompok kontrol, dapat dilihat pada Tabel 10. Hasil uji statistik menunjukkan bahwa pada kelompok perlakuan ada perbedaan TDS antara awal dengan akhir penelitian, namun tidak berbeda pada TDD.

Berdasarkan kriteria pengendalian tekanan darah, tampak proporsi untuk kedua kelompok mengalami perubahan. Proporsi subjek dengan pengendalian tekanan darah baik dan sedang sama-sama meningkat untuk kedua kelompok (Tabel 11).

Beberapa penelitian mengungkapkan bahwa perubahan gaya hidup seperti menurunkan asupan energi, lemak dan natrium serta meningkatkan aktivitas fisik terbukti dapat menurunkan tekanan darah. Dengan penurunan BB laki-laki sebesar 4,7 kg dan perempuan sebesar $1,6 \mathrm{~kg}$, dijumpai rerata penurunan TDS/TDD secara berurutan sebesar $3,2 / 2,8 \mathrm{mmHg}( \pm 0,43 / 0,37)$ dan $2,0 / 1,1 \mathrm{mmHg}( \pm 0,27 / 0,15)(38)$. Hasil meta-analisis dijumpai adanya kesamaan efek antara penurunan $4,5 \mathrm{~kg}$ BB dengan terapi obat anti hipertensi terhadap pengendalian tekanan darah. Dari penelitian tersebut juga didapatkan bahwa dengan pembatasan natrium sebesar
$2400 \mathrm{mg} / \mathrm{hari}$ efektif menurunkan TDS dan TDD secara berurutan sebesar $6 \mathrm{mmHg}$ dan $2 \mathrm{mmHg}(13)$.

Hasil penelitian lain yang sejalan adalah penelitian pada 302 penyandang hipertensi, dislipidemia dan DM tipe 2 yang dilakukan di 5 pusat kesehatan berbasis universitas (Oregon Health Sciences University, Portland; Pennsylvania State University, University Park; St Luke/ Roosevelt Hospital, New York; Universitas Alabama, Birmingham, dan University of California, Davis). Dengan melakukan intervensi berupa pemberian prepared meal plan (PMP) dan usual care diet (UCD) selama 1 tahun, dijumpai adanya penurunan BB sebesar $3,0 \mathrm{~kg}( \pm 5,4)$ dan $1,0 \mathrm{~kg}( \pm 3,8)$. Sedangkan hasil pengukuran tekanan darah, tidak terdapat perbedaan yang signifikan antara kedua kelompok, meskipun rata-rata tekanan darah pada kedua kelompok menurun signifikan antara awal dan akhir penelitian $(p<0,001)$. Dijelaskan pada penelitian tersebut bahwa tidak signifikannya perbedaan efek yang ditimbulkan tersebut terkait dengan penurunan asupan lemak yang tidak adekuat, di mana rerata asupannya mencapai 35\% dari kebutuhan energi total (39).

Jika dikaitkan dengan temuan pada penelitian ini (Tabel 11), tampak pada kedua kelompok terjadi penurunan TDS, namun perbedaan yang bermakna antara awal dengan akhir penelitian hanya terjadi pada kelompok perlakuan $(p<0,05)$. Hal ini kemungkinan akibat singkatnya penelitian serta rerata asupan lemak yang masih lebih tinggi dari jumlah yang direkomendasikan, meskipun telah mengalami penurunan bermakna. Akibatnya berefek pada penurunan berat badan yang tidak adekuat yang hanya sebesar 1,07 kg. Dengan penurunan sejumlah tersebut belum mampu memperbaiki resistensi insulin secara optimal, sehingga kondisi hiperinsulinemia tetap terjadi. Akibatnya aktivitas saraf simpati tetap tinggi dan kondisi hipervolemia tetap ada. Oleh karena itu tekanan darah

Tabel 10. Perubahan tekanan darah kelompok perlakuan dan kontrol

\begin{tabular}{lcccc}
\hline & \multicolumn{2}{c}{ Perlakuan } & \multicolumn{2}{c}{ Kontrol } \\
\cline { 2 - 5 } & Mean (SD) & $\mathbf{p}$ & Mean (SD) & $\mathbf{p}$ \\
\hline TDS awal $(\mathrm{mmHg})$ & $135,33( \pm 19,78)$ & 0,035 & $137,33( \pm 15,74)$ & 0,282 \\
TDS akhir $(\mathrm{mmHg})$ & $131,00( \pm 14,23)$ & & $135,00( \pm 16,56)$ & \\
TDD awal $(\mathrm{mmHg})$ & $83,67( \pm 9,91)$ & 0,895 & $86,67( \pm 8,23)$ & 0,203 \\
TDD akhir $(\mathrm{mmHg})$ & $83,83( \pm 5,83)$ & & $84,83( \pm 7,82)$ & \\
Delta TDS $(\mathrm{mmHg})$ & $-3,33( \pm 10,61)$ & & $-1,67( \pm 10,53)$ & $\mathrm{F}=0,09, \mathrm{p}=0,754$ \\
Delta TDD $(\mathrm{mmHg})$ & $0,5( \pm 6,87)$ & & $-1,33( \pm 7,30)$ & $\mathrm{F}=0,10, \mathrm{p}=0,752$ \\
\hline
\end{tabular}

Tabel 11. Perubahan proporsi kelompok perlakuan dan kontrol berdasarkan kriteria pengendalian tekanan darah

\begin{tabular}{lrrrr}
\hline \multirow{2}{*}{$\begin{array}{c}\text { Kategori } \\
\text { pengendalian } \\
\text { tekanan darah }\end{array}$} & Awal & Akhir & Awal & Kontrol \\
\cline { 2 - 5 } & $\mathbf{n ~ ( \% )}$ & $\mathbf{n ~ ( \% )}$ & $\mathbf{n}(\%)$ & $\mathbf{n}(\%)$ \\
\hline Baik & $10(33,3 \%)$ & $14(46,7 \%)$ & $6(20,0 \%)$ & $7(23,3 \%)$ \\
Sedang & $10(33,3 \%)$ & $12(40,0 \%)$ & $14(46,7 \%)$ & $16(53,3 \%)$ \\
Buruk & $10(33,3 \%)$ & $4(13,3 \%)$ & $10(33,3 \%)$ & $7(23,3 \%)$ \\
\hline
\end{tabular}


tidak menurun secara bermakna $(5,40)$. Demikian pula dengan asupan natrium, dijumpai asupan natrium pada kedua kelompok pada penelitian ini masih relatif tinggi, walaupun jumlah tersebut telah mengalami penurunan dari natrium awal. Sedangkan penelitian yang mendapatkan efek nyata terhadap penurunan TDS dan TDD adalah bila pembatasan natrium maksimal sebesar $2400 \mathrm{mg} /$ hari pada pasien dengan hipertensi.

\section{KESIMPULAN DAN SARAN}

Asupan zat gizi (energi, lemak, karbohidrat dan natrium), pengendalian status gizi dan kadar glukosa darah pasien DM tipe 2 yang mendapat TGM lebih baik dibandingkan yang mendapat konseling gizi konvensional. Adapun penurunan tekanan darah, khususnya tekanan darah sistolik cenderung lebih baik pada pasien DM tipe 2 yang mendapat TGM dibandingkan yang mendapat konseling gizi konvensional.

Untuk mendapatkan efek optimal TGM terhadap pengendalian DM secara keseluruhan, perlu dilakukan sosialisasi dan advokasi pada dokter dan petugas kesehatan lain yang terkait dengan tim asuhan gizi rumah sakit. Hal ini agar dapat terjalin kerjasama tim yang lebih baik sehingga monitoring pencapaian sasaran kendali glikemik pasien DM tipe 2 melalui TGM dapat dilakukan secara komperehensif dan berkesinambungan.

\section{RUJUKAN}

1. Suyono S. Diabetes mellitus di Indonesia. dalam Sudoyo AW, Setiyohadi B, Alwi I, Simadibrata M, Setiati S. eds. Buku ajar ilmu penyakit dalam edisi IV. Jilid 3. Jakarta: Pusat Penerbitan Departemen IImu Penyakit Dalam FKUI; 2006.

2. Franz MJ. Medical nutrition therapy for diabetes and hypoglycemia of nondiabetic origin. In Mahan L.K. dan Escott-Stump S. Krause's Food, nutrition and diet therapy. $11^{\text {th }}$ Ed. Philadelpha PA: W.B. Saunders; 2004.

3. Wiardani NK, Hadi H, Huriyati E. Pola makan dan obesitas sebagai faktor risiko DM tipe 2 di rumah sakit Sanglah Denpasar. Jurnal Gizi Klinik Indonesia 2007; 4(1): 1-10.

4. PERKENI. Konsensus pengelolaan dan pencegahan diabetes mellitus tipe 2 di Indonesia. Jakarta: PBPERKENI; 2006.

5. Wiyono P. Terapi hipertensi pada DM tipe 2. dalam Asdie AH, Widayati K, Suyanto, Ikhsan, MR. eds. naskah lengkap PIT VI Endokrin Joglosemar. Updating the knowledge of recent advances in basic and clinical endocrinology. Inna garuda Hotel. Yogyakarta: Medika FK UGM; 2005.

6. Tesfaye F, Nawi NG, Minh HV, Berhane Y, Bonita R, Wall S. Association between body mass index and blood pressure across three populations in Africa and Asia. Journal of Human Hypertension 2007; 21: 28-37.

7. Adam JMF. Central obesity and metabolic syndrome. dalam Asdie AH, Aswin S, Wiyono P, Rochmah W, Pramantara IDP, Bayupurnama P, Widayati K, Hilda S. eds. Naskah Lengkap PIT IV Endokrin 2003. FK UGM/ RS Dr. Sardjito Yogyakarta, FK UNDIP/RS Dr. Karyadi Semarang. Sheraton Mustika Hotel, 13-14 Desember. Yogyakarta: Medika FK UGM Bekerjasama dengan Pendidikan Berkelanjutan Bagian IImu Penyakit Dalam FK UGM; 2003.

8. Hayashi T, Boyko EJ, McNeely MJ, Leonetti DL, Kahn SE, Fujimoto WY. Minimum waist and visceral fat values for identifying japanese americans at risk for metabolic syndrome. Diabetes Care 2007; 30: 1207.

9. Widiastuti N, Subagio HW. Hubungan beberapa indikator obesitas dengan hipertensi. M Med Indones 2006; 41 (1):10-6.

10. Juleka, Asdie AH, Susetyowati. Hubungan pola makan dengan pengendalian kadar glukosa darah pengidap dm tipe 2 rawat jalan di RSU Gunung Jati Cirebon. Jurnal Gizi Klinik Indonesia 2005. [serial online] 2005 [cited 2010 Oct 14]; 2(1). Available from: www.ijcn. or.id.

11. Yunsheng, Barbara C, Olendzki, Andrea R, Hafner, David E. Low-carboydrate and high-fat intake among adult patients with poorly controlled type 2 diabetes mellitus. [serial online] 2006 [cited 2007 July 31]. Available from: http://www.diabetes.org.

12. Varughese GI, Patel JV, Lip GYH. Blood pressure control in the setting of diabetes mellitus: new targets, new hope for improvement? (Commentary) Journal of Human Hypertension 2006. [serial online] 2006 [cited 2007 August 8]; 20. Available from: http://www.nature. $\mathrm{com} / \mathrm{jhh}$.

13. Christensens NK, Steiner J, Whalen J, Pfister R. Contribution of medical nutrition therapy and diabetes self-management education to diabetes control as assessed by hemoglobin $A_{1 c}$. Diabetes Spectrum 2000. American Diabetes Association [serial online] 2000 [cited 2007 July 28]; 13(2):72. Available from: http:// www.diabetes.org.

14. Pastors JG, Franz MJ, Warshaw H, Daly A, Arnold MS. How effective is medical nutrition therapy in diabetes care?. J Am Diet Assoc 2003;103: 827-31.

15. Depkes RI. Pedoman praktis terapi gizi medis. Jakarta: Dirjen Bina Kesehatan Masyarakat Direktorat Gizi Masyarakat; 2006.

16. Yuliati A, Gunawan MA, Budiningsari RD. Pelaksananaan asuhan gizi dengan pendekatan terapi gizi medis (TGM) berpengaruh terhadap asupan gizi pasien di RSUD Kota Bekasi. Jurnal Gizi Klinik Indonesia 2008; 5(1). 
17. Waspadjie S. Sindroma metabolik: peran dietisien pada pengelolaannya. Prosiding AsDI Jawa Barat PIT Dietetic II; 2005 Feb18-19. Bandung; 2005.

18. Reppie MR, Asdie AH, Astuti H. Pengaruh konseling gizi dengan buku saku diet pada pasien hiperurisemia rawat jalan di RSUD Noongan Provinsi Sulawesi Utara. Jurnal Gizi Klinik Indonesia 2007; 4(1): 35-42.

19. Lemeshow S, Hesmen Jr DW, Klar J. Besar sampel dalam penelitian kesehatan. Yogyakarta :Gadjah Mada University Press; 1997.

20. Kim SH, Lee SJ, Kang ES, Kang S, Hur KY, Lee HJ. Effects of lifestyle modification on metabolic parameters and carotid intima-media thickness in patients with type 2 diabetes. J Am Diet Assoc 2006; 55 (Pt 8): 1053-9.

21. American Diabetes Association. Practice guidelines for medical nutrition therapy provided by dietitians for person with non-insulin-dependent diabetes mellitus. J Am Diet Assoc 1995; 95: 999-1006.

22. Profil Rumah Sakit Umum Mataram Provinsi Nusa Tenggara Barat; 2006.

23. Glasgow RE, Toobert DJ, Hampson SE, Lewinsohn PM, Donelly J. Improving self-care among older patiens with tipe ii diabetes: "Sixty-something..." Studi. Patient Educ.\&couns 19; 1992.

24. Ziemer DC, Berkowitz KJ, Panayioto RM, El-Kebbi IM, Musey VC, Anderson LA. A simpel meal plan emphasizing healthy food choice is as effective as an exchange-based meal plan for Urban African Americans with Tipe 2 Diabetes. Diabetes Care 2003; 26:171924.

25. Curry KR, Jaffe A. Nutrition counselling and communication skills. WB Saunders Company; 1998.

26. American Diabetes Association. Nutrition recommendations and interventions for diabetes -2006 (Position Statement). Diabetes Care 2006;_29:214057.

27. American Diabetes Association. Position statement: standards of medical care in diabetes. Diabetes Care 2007; 30:S4-S41.

28. Povey R, Conner M, Spark P, James R, Shepherd $R$. A critical examination of the aplication of the transtheoretical model's stage of change to dietary behaviours. Health Education Research, Theory \& Practice 1999; 14 (5): 641-51.

29. Barinas ME, Kuller LH, Tyrrell S, Hegazi R, Harper $P$, Mancino J, Kelley DE. Effect of weight loss and nutritional intervention on arterial stiffness in tipe 2 diabetes. Diabetes Care 2006; 26: 2218-22.

30. Dansinger M L, Tatsioni A, Wong J B, Chung M, Balk EM. Meta-analysis: the effect of dietary counseling for weight loss. Ann Intern Med 2007; 147: 41-50.

31. Chalmers KH. Medial nutrition therapy. In Kahn CR, Weir GC, King GL, Jacobson AM, Moses AC, Smith
RJ. eds. Joslin's Diabetes $14^{\text {th }}$. Philadephia: Lippincott Williams \& Walkins a Wolter Kluwer Company; 2005.

32. Cheah JS. Management of obesity in NIDDM. Asia Pacific J Clin Nutr 1998; 7(3/4): 282-6.

33. Pemayun TGD, Djokomoeljanto R, Suhartono T, Darmono, Setiawan H, Djokomoeljono T. Prevalensi sindroma metabolik pada pekajangan diabetes study .dalam Asdie AH, Aswin S, Wiyono P, Rochmah W, Pramantara IDP, Bayupurnama P, Widayati K, Hilda S. eds. Naskah Lengkap PIT IV Endokrin 2003. FK UGM/ RS Dr. Sardjito Yogyakarta, FK UNDIP/RS Dr. Karyadi Semarang. Sheraton Mustika Hotel, 13-14 Desember. Yogyakarta: Medika FK UGM bekerjasama dengan Pendidikan Berkelanjutan Bagian IPD FK UGM; 2003.

34. Mendoza JA, Drewnowski A, Christakis DA. Dietary energy density is associated with obesity and the metabolic syndrome in U.S. adults. [serial on line] 2007 [cited 2007 August 8]. Available from: http:// www.diabetes.org.

35. Norris SL, Engelgau MM, Narayan KMV. Effectiveness of self management training in Tipe 2 diabetes. a systematic review of RCT. Diabetes Care 2001; 24:561-87.

36. Franz MJ, Splett PL, Monk A, Barry B, McClain K, Weaver T, Upham P, Bergenstal R, Mazze RS. Costeffectiveness of medial nutrition therapy provided by dietitians for person with non-insulin-dependent diabetes mellitus. J Am Diet Assoc 1995; 95:101824.

37. Kulkarni K, Castle G, Gregory R, Holmes A, Leontos C, Powers M, Snetselaar L, Splett P, Wylie-Rosset J. Nutrition practice guideline for tipe 1 diabetes mellitus possitively affect dietitian practices and patient outcomes. J Am Diet Assoc 1998; 98:62-70.

38. Hendromartono. Implication of recent endpoint trials on current and future dyslipidemia and diabetic patiens. dalam Asdie AH, Aswin S, Wiyono P, Rochmah W, Pramantara IDP, Bayupurnama P, Widayati K, Hilda S. eds. Naskah Lengkap PIT IV Endokrin 2003. FK UGM/ RS Dr. Sardjito Yogyakarta, FK UNDIP/RS Dr. Karyadi Semarang. Sheraton Mustika Hotel, 13-14 Desember. Yogyakarta : Medika FK UGM bekerjasama dengan Pendidikan Berkelanjutan Bagian IImu Penyakit Dalam FK UGM; 2003.

39. WHO. Pengendalian hipertensi, laporan komisi pakar WHO. Alih Bahasa oleh Padmawinata K. Bandung: Penerbit ITB; 1996.

40. Metz JA, Stern JS, Etherton K, Reusser ME, Morris CD. A randomized trial of improved weight loss with a prepared meal plan in overweight and obese patiens. Arch Intern Med 2000; 160: 2150-58. 